\title{
Beginning Teachers Are More Common in Rural, High-Poverty, and Racially Diverse Schools
}

\author{
DOUGLAS GAGNON AND MARYBETH J. MATTINGLY
}

$\mathrm{T}$ eaching is a difficult craft, one that requires time to master. The first years of one's teaching career provide vast opportunities for professional growth, yet new teachers have fewer experiences to draw on in planning lessons, managing classrooms, and creating assessment strategies. Therefore, beginning teachers are typically less effective than their more experienced colleagues, as measured by student achievement gains. ${ }^{1}$ This measure of teacher quality-whether or not a teacher is a novice-is fairly unique as it is both easy to measure and consistently tied to effectiveness; most other quality indicators are either difficult to measure (for example, certain classroom behaviors) or else do not exhibit a robust connection to student achievement (such as advanced degree status). Additionally, beginning teachers are more likely to leave the profession than those who have weathered at least a few years in the classroom. ${ }^{2}$ Thus, employing a large percentage of beginning teachers is costly both to a district and students. For these reasons, the concentration of beginning teachers is an important dimension of school quality.

We consider whether the concentration of beginning teachers (defined as teachers in their first or second year of teaching) in a district is associated with the district's poverty rate, racial composition, or urbanicity. The categories of urbanicity we use here include large city, midsized-small city, suburb, fringedistant town, remote town, and rural. See the data section for details. We combined data from the 2009-2010 Civil Rights Data Collection (CRDC), the 2009 Small Area Income and Poverty Estimates (SAIPE), and the 2010 U.S. Census to form a nationally representative data source of 6,569 districts.

\section{Concentration of Beginning Teachers Varies Widely}

Across America, an estimated 9.3 percent of a district's teaching staff is composed of beginning teachers. This number varies substantially across districts, however. As shown in Figure 1 , one-half of the districts - those between the 25th and 75th percentiles-employ between 4.5 percent and 12.1 percent

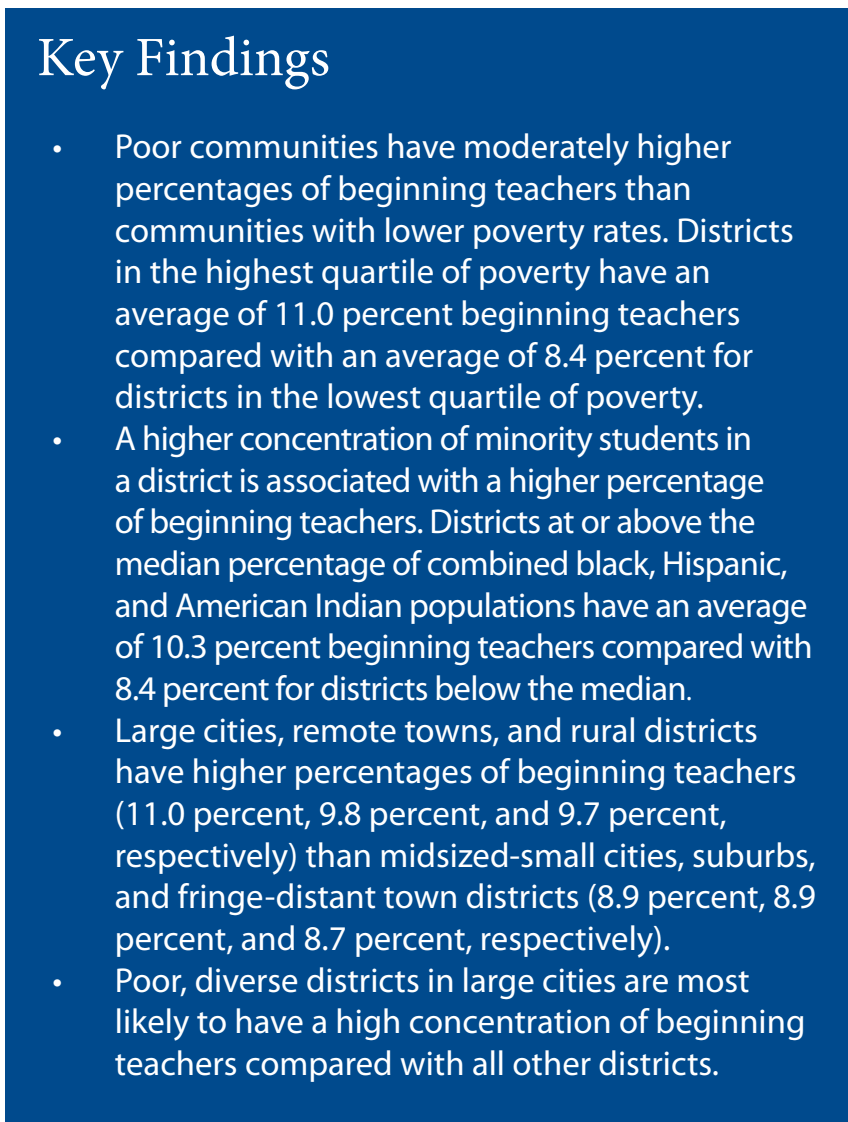

beginning teachers, on average. This represents a nearly three-fold difference and equates to a student in a school at the 25th percentile receiving one more year of instruction by a beginning teacher than a student in a school at the 75th percentile, on average. Large differences are also evident at the state level. State averages for first- or second-year teachers in our sample varied from a low of 5.5 percent in Michigan to a high of 22.4 percent in Florida, with Washington, DC employing 41.9 percent beginning teachers. 
Figure 1: Average PerCentage of BeginNing TEACHERS IN SCHOOL DISTRICTS, BY QUARTILES

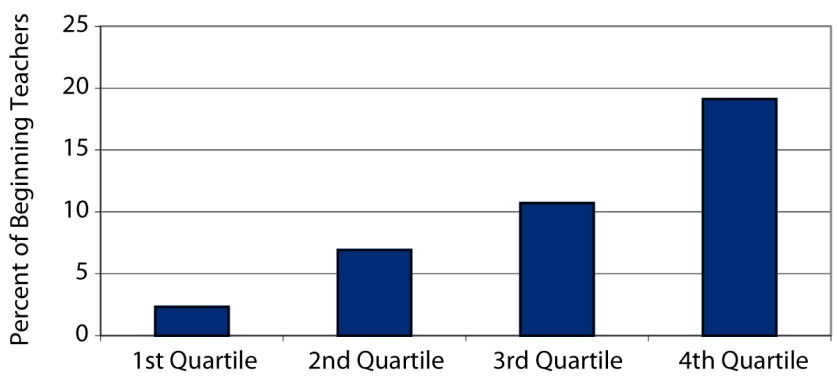

\section{High Poverty Is Associated With} a Higher Percentage of Beginning Teachers

On average districts have 16.8 percent of their students living in poverty. Poverty is modestly, though statistically significantly, correlated with the concentration of beginning teachers in a district. In the less poor districts (top quartile), only 8.4 percent of teachers are new, while in the poorest districts (bottom quartile), 11.0 percent are new. This experience difference equates to approximately one-third of an additional school year of novice instruction, on average, for students in the poorest districts compared with those in the most affluent districts.

\section{Black, Hispanic, and American Indian School Populations Are Associated With a Higher Percentage of Beginning Teachers}

The district average share of black, Hispanic, and American Indian students in our sample is 10.5 percent, 13.3 percent, and 2.6 percent, respectively. In general, as districts become more urban, they also become more diverse, with the exception of remote towns, which have a slightly higher percentage of minorities than fringe-distant towns. In addition, districts with high percentages of black, Hispanic, and American Indian populations have greater shares of novice teachers. ${ }^{3}$ Districts in the top half of the distribution (more diverse) reported 10.3 percent of beginning teachers, on average, compared with only 8.4 percent for districts in the bottom half; the correlation of these minority populations with beginning teachers was modestly statistically significant.

\section{Large Cities, Remote Towns, and Rural Districts Have the Highest Percentage of Beginning Teachers}

Large cities, remote towns, and rural areas have significantly higher percentages of beginning teachers than suburbs, fringedistant towns, and midsized-small cities. Table 1 shows the average percentage of beginning teachers for each category of urbanicity, as well as average poverty and racial composition. Among all the locales, large cities have the highest rates of beginning teachers as well as the greatest percentage of minority students. Remote towns rank next in concentration of novice teachers and exhibit the highest rate of students living in poverty. Rural areas have much smaller poverty and minority compositions than remote towns, but display a comparable average percentage of beginning teachers.

\section{A “Critically High" Percentage of Beginning Teachers}

Perhaps more important than the overall concentration of beginning teachers is whether that share exceeds a critical value. Having some beginning teachers is arguably a good thing: new teachers bring excitement and new pedagogical techniques to a school. On the other hand, districts with a small concentration of beginning teachers may find it easier-and less costly - to mentor those teachers than districts with a high percentage of beginning teachers. ${ }^{4}$ Research has shown that beginning teachers without a mentor are much more likely to leave the profession than those with a mentor. ${ }^{5}$ Also, if a district has too many beginning teachers, it may no longer have the resources to meet its instructional and professional development needs.

We define a critical value at greater than 17 percent new teachers. This captures the top 10 percent of districts with the largest share of beginning teacher in our sample. Seventeen percent is nearly twice the sample average, and translates roughly to receiving nearly twice as much instruction from new teachers as students in an average district.

\section{Poor, Diverse, Large Cities Are Most Likely to Have a Critically High Percentage of Beginning Teachers}

From our analysis, we were able to estimate the probability that a district would have a critically high percentage of beginning teachers on the basis of the racial composition (the sum percentage of black, Hispanic, and American Indian students), poverty rate, and urbanicity of the district. ${ }^{6}$ Our analysis also allows us to compare, for instance, a rural district that is poor 
TABle 1. MeAn PERCENT OF Beginning TeAChers, POVERTy, AND RACE, By URBANiCity

\begin{tabular}{|c|c|c|c|c|c|c|c|}
\hline & Full Sample & $\begin{array}{l}\text { Large } \\
\text { Cites }\end{array}$ & $\begin{array}{l}\text { Midsized- } \\
\text { Small Cities }\end{array}$ & Suburbs & $\begin{array}{c}\text { Fringe- } \\
\text { Distant } \\
\text { Towns }\end{array}$ & $\begin{array}{l}\text { Remote } \\
\text { Towns }\end{array}$ & Rural \\
\hline Percent of beginning teachers & 9.3 & 11.0 & 8.9 & 8.9 & 8.7 & 9.8 & 9.7 \\
\hline Percent of students in poverty & 16.8 & 21.9 & 19.6 & 11.7 & 18.2 & 22.1 & 17.9 \\
\hline $\begin{array}{l}\text { Sum percent of black, Hispanic, } \\
\text { and American Indian students }\end{array}$ & 26.4 & 61.2 & 43.9 & 28.3 & 26.0 & 31.3 & 19.2 \\
\hline Sample size & 6,569 & 151 & 537 & 1,811 & 789 & 497 & 2,784 \\
\hline
\end{tabular}

Note. Large city is a territory inside an urbanized area and inside a principle city with a population of 250,000 or more; midsized-small city: Territory inside an urbanized area and inside a principle city with a population less than 250,000; suburb: Territory outside a principal city and inside an urbanized area; fringe-distant town: Territory inside an urban cluster that is located less than or equal to 35 miles from an urbanized area; remote town: Territory inside an urban cluster that is located more than 35 miles from an urbanized area; rural: Territory outside an urban cluster or urbanized area

and diverse by rural standards to a suburban district that is poor and diverse by suburban standards. Given that poverty and racial-ethnic makeup tend to be correlated, it makes sense to examine these differences in poverty and race together.

Figure 2 shows that the large cities are the likeliest to have a critically high percentage of beginning teachers when comparing districts of average poverty and diversity. As the figure shows, the probability is roughly twice that of a midsized-small city, suburb, or fringe-distant town. The next highest probabilities are for rural areas and remote towns.

\section{Figure 2: Probabilities OF A CRitically High}

PERCENTAGE OF BEGINNING TEACHERS, BY URBANICITY

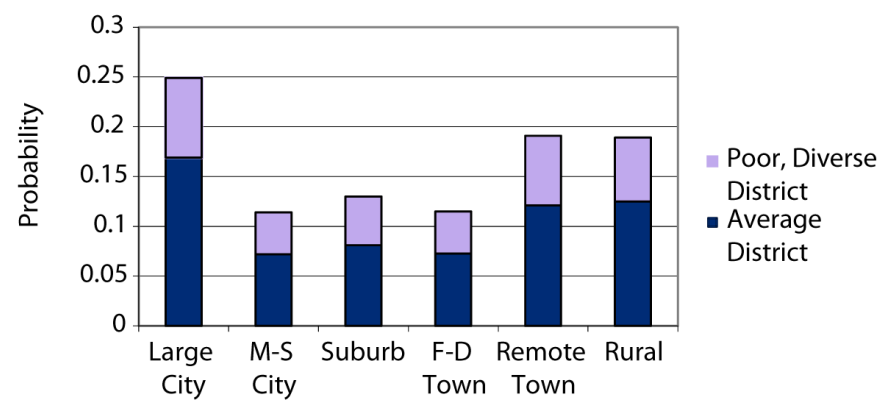

Among districts that are poor and diverse, the probability of having a critical percentage of beginning teachers is also highest for large cities. Thus, large urban districts are the most likely to have a critically high percentage of beginning teachers when districts of average poverty and diversity, as well as districts that are poor and diverse, are analyzed across urbanicity. Poor, diverse remote towns experience the next largest difference in probability when compared to an average remote town district. Poor, diverse districts in remote towns and rural areas show a substantially higher probability than poor, diverse districts in midsize-small cities, suburbs, and fringe-distant towns.

Although the individual relationship between any single measure of poverty and place has only a weak to moderately strong relationship to the concentration of beginning teachers in a district, their cumulative effects appear more meaningful. Poor, diverse districts in remote towns and rural areas have approximately twice the probability of having a critically high percentage of beginning teachers than midsized-small city, suburban, and fringe-distant town districts of average poverty and diversity. For poor, diverse, large cities, this difference in probability is nearly three-fold. This analysis highlights the combined impact that poverty, race, and urbanicity have on beginning teacher proportions.

\section{Discussion}

The concentration of beginning teachers in a district speaks to teacher hiring and development, and more directly to the average teacher quality in the district. A high percentage of beginning teachers requires more teacher development and likely reflects higher teacher turnover in the district. Research suggests that teachers move out of high-minority and high-poverty schools at a disproportionately high rate. Moreover, large urban districts are often noted for having unique staffing challenges and issues. ${ }^{8}$ Research suggests that salary only modestly affects teachers' decisions to leave, while improved working conditions (such as less challenging students or working closer to home) largely drive teacher migration. ${ }^{9}$ This leads to greater hiring demands and associated costs in those districts with higher teacher turnover.

Although beginning teachers are paid less than their more experienced peers, these savings may be largely outstripped by the costs of hiring new teachers, as research suggests this to be a financial burden on states 
and districts. ${ }^{10}$ Our findings regarding high minority, high poverty, and urban districts generally support past research that suggests districts with these qualities face greater staffing challenges.

In addition to suggesting a higher rate of teacher turnover, a high percentage of beginning teachers might also suggest issues of teacher quality within a district. This is of profound importance, as teacher quality matters a great deal in student outcomes. Research has consistently shown substantial variation in the ability of teachers to raise student achievement. ${ }^{11}$ The concentration of beginning teachers in a district provides a convenient lens to analyze one aspect of teacher quality, largely because there is a lack of robust, well-established, and widely measured indicators of teacher effectiveness. Those proxies of quality that are ubiquitously measured-advanced degrees and experience-are fairly weak predictors of teacher effectiveness (not to be confused with whether or not a teacher is in the first or second year of teaching, which has been shown to be a fairly well-established predictor of teacher effectiveness). Some measures of quality that do appear to be better linked to teacher effectiveness-such as strong content knowledge, academic profile, verbal ability, and certain classroom behaviors ${ }^{12}$ - are not measured as consistently and therefore cannot be used in a national study such as this. Therefore, the concentration of beginning teachers is a meaningful way to access a component of teacher effectiveness in a national, district-level study of equity.

A further area of study could examine differences in beginning teacher concentration between states. Exploratory analysis suggests that this paper's findings regarding the impact of poverty, race, and urbanicity on beginning teacher concentration generally holds true within states as well. Therefore, much of the variation between states is unique (not simply a result of differences in poverty, race, and urbanicity between the states). The differences in the district-average beginning teacher concentration across states could result in part from state policies related to teacher staffing.

Our analysis builds upon prior research that has shown a disparity in educational opportunity and achievement. Those schools most likely to have a high percentage of beginning teachers-large cities, remote towns, rural areas; those of high poverty and diversity - serve those students who are often outperformed by their peers. Recent research suggests that suburban students outperform their urban and rural peers, ${ }^{13}$ and that black, Hispanic, and American Indian students lag behind their white peers in reading achievement. ${ }^{14}$ This research also suggests that higher poverty is associated with lower levels of achievement. Furthermore, rural students have been shown to have less access to advanced mathematics courses..$^{15}$ It is those students who consistently lag behind and have fewer opportunities than their peers who are also the most likely to receive instruction from beginning teachers. Thus, although differences in the concentration of beginning teachers between these groups of students is not of great magnitude, it does support the argument that there are cumulative differences in the quality of education for rural, urban, and minority students. This paper contributes to an established body of evidence that educational opportunities are not equal across poverty and place.

\section{Data}

The data in this brief are from three sources: the 2009-2010 Civil Rights Data Collection (CRDC), the 2009 Small Area Income and Poverty Estimates (SAIPE), and the 2010 U.S. Census. The CRDC is a mandatory data collection which provides district-level information on the number of first- and second-year teachers as well as information on student racial composition for the 2009-2010 school year. Districts were given the option of reporting by either the traditional five population categories (American Indian/ Alaskan Native, Asian/Pacific Islander, Hispanic, black, and white) or the newer seven population categories, which splits Asian/Pacific Islander into separate categories of Asian and Native Hawaiian/Pacific Islander and adds the category of "two or more races." Because only about one-fourth of districts reported using the seven population categories, we used "Asian/Pacific Islander" as a category in this analysis. Because of its small effect size and heterogeneous grouping, results on this race were not reported. We excluded the category of "two or more races" because it occurred in only a minority of districts.

SAIPE provides information on the number of students in a district living in poverty. The U.S. Census provides information on urbanicity. The CRDC uses a nationally representative sample, whereas the SAIPE and Census provide information on nearly all districts. We merged these three data sets using the National Center for Education Statistics district ID code. We dropped any districts from the SAIPE and Census that were not included in the CRDC. Therefore, the sample used in this brief is essentially a modified district-level data set from the CRDC, with 6,569 districts in total. This is not a weighted sample, and therefore the estimates are not national estimates. This limits the generalizability of these results beyond those districts sampled.

\section{Urbanicity Categories}

The U.S. Census reports urbanicity using a 12-point classification scheme. This includes four major types: city, suburb, town, and rural. Each of these types has three subcategories: population gradations of large, medium, and small for city and suburb; distance from urbanized area gradations of 
fringe, distant, and remote for towns and rural areas. The major types were preserved in this analysis due to differences within the categories. We used tests of the mean to determine whether there were statistically significant differences in beginning teacher proportions within each of the major types. Where differences did not exist-for example, in large, medium, and small suburbs; fringe and distant towns-we collapsed the subcategories for ease of interpretation. This resulted in six categories of urbanicity: large city, midsizedsmall city, suburb, fringe-distant town, remote town, and rural. These categories are defined as follows:

- Large city-Territory inside an urbanized area and inside a principle city with a population of 250,000 or more.

- Midsize-small city-Territory inside an urbanized area and inside a principle city with a population less than 250,000 .

- Suburb-Territory outside a principal city and inside an urbanized area.

- Fringe-distant town-Territory inside an urban cluster that is located less than or equal to 35 miles from an urbanized area.

- Remote town-Territory inside an urban cluster that is located more than 35 miles from an urbanized area.

- Rural-Territory outside an urban cluster or urbanized area.

\section{E N D N O T ES}

1. L. Darling-Hammond, Teacher Quality and Student Achievement: A Review of State Policy Evidence (Seattle, WA: Center for the Study of Teaching and Policy, University of Washington, 1999); J. E. Rockoff, “The Impact of Individual Teachers on Student Achievement: Evidence from Panel Data, American Economic Review, vol. 94, no 2 (2004): 247 252; B. Nye, S. Konstantopoulos, and L. Hedges, "How Large Are Teacher Effects?" Educational Evaluation and Policy Analysis, vol. 26, no. 3 (2004): 237-257; E. A. Hanushek, et al., "The Market for Teacher Quality," NBER Working Paper No. 11154 (Cambridge, MA, National Bureau of Economic Research, 2005).

2. Eric A. Hanushek and S. G. Rivkin, "Pay, Working Conditions, and Teacher Quality," Future of Children, vol. 17, no. 1 (2007): 69-86.

3. Each of these three population groups exhibits a similar relationship to the beginning teacher concentration in a district. Therefore, for ease of interpretation, we analyzed the sum percentage of black, Hispanic, and American Indian students. The sum percentage shows a modest correlation with the concentration of beginning teachers in a district.

4. M. Strong, Effective Teacher Induction and Mentoring: Assessing the Evidence (New York: Teachers College Press, 2009).
5. A. Kaiser, "Beginning Teacher Attrition and Mobility: Results from the First through Third Waves of the 2007-08 Beginning Teacher Longitudinal Study. First Look." NCES 2011-318 (Washington, DC: National Center for Education Statistics, 2011).

6. We simultaneously considered the role of poverty rates, racial composition, and urbanicity using a logistic regression model. Remote towns have the highest percentage of students in poverty, followed closely by large cities, with suburbs having the lowest levels of poverty. Moreover, remote towns also exhibit the greatest variation in poverty in our sample. Large cities are by far the most racially diverse. However, remote towns show greater variation in the sum percentage of black, Hispanic, and American Indian students than large cities do. Therefore, it is useful to not only examine the probability that an average district has a critically high percentage of beginning teachers, but also the probability that a poor, diverse district in each category of urbanicity has a critically high percentage of beginning teachers, as poor and diverse take on different meanings across different categories of urbanicity. A poor, diverse district is defined here as having a concentration of students living in poverty and a sum percentage of black, Hispanic, and American Indian students that is one standard deviation above the mean for that particular category of urbanicity.

7. L. Darling-Hammond and G. Sykes, "Wanted: A National Teacher Supply Policy for Education: The Right Way to Meet the 'Highly Qualified Teacher' Challenge," Education Policy Analysis Archives, vol. 11 (2003): 33; E. Hanushek, J. F. Kain, and S. G. Rivkin, "Why Public Schools Lose Teachers," Journal of Human Resources, vol. 39, no. 2 (2004): 326-354.

8. J. Levin, J. Mulhern, and J. Schunck, "Unintended Consequences: The Case for Reforming the Staffing Rules in Urban Teachers Union Contracts," The New Teacher Project (New York, NY: 2005). G. Barnes and E. Crowe, “The Cost of Teacher Turnover in Five School Districts: A Pilot Study" (Washington, DC: National Commission on Teaching and America’s Future, 2007).

9. Hanushek and Rivkin, "Pay, Working Conditions, and Teacher Quality."

10. Barnes and Crowe, "The Cost of Teacher Turnover in Five School Districts: A Pilot Study.”

11. Rockoff, "The impact of individual teachers"; Nye et al., "How Large Are Teacher Effects?"; Hanushek et al., "The Market for Teacher Quality."

12. D. H. Gitomer, "Teacher Quality in a Changing Policy Landscape: Improvements in the Teacher Pool," Policy Information Report (Princeton, NJ: Educational Testing Service, 2007); Darling-Hammond, Teacher Quality and Student Achievement; J. H. Stronge, T. J.Ward, and L. W. Grant, "What Makes Good Teachers Good? A Cross-Case 
Analysis of the Connection between Teacher Effectiveness and Student Achievement," Journal of Teacher Education, vol. 62, no 4 (2011): 339-355.

13. S. E. Graham and C. Teague, "Reading Levels of Rural and Urban Third Graders Lag Behind Their Suburban Peers," Issue Brief No. 28 (Durham, NH: Carsey Institute, University of New Hampshire, 2011).

14. W. W. Grigg, R. R. Moran, and M. M. Kuang, "National Indian Education Study-Part I: Performance of American Indian and Alaska Native Students at Grades 4 and 8 on NAEP 2009 Reading and Mathematics Assessments," NCES 2010-462 (Washington, DC: National Center For Education Statistics, 2010).

15. S. E. Graham, "Students in Rural Schools Have Limited Access to Advanced Mathematics Courses," Issue Brief No. 7 (Durham, NH: Carsey Institute, University of New Hampshire, 2009).

\section{ABOUT THE AUTHORS}

Douglas Gagnon is a doctoral candidate in education at the University of New Hampshire and a research assistant at the Carsey Institute (djb492@wildcats.unh.edu).

Marybeth J. Mattingly is the director of research on vulnerable families at the Carsey Institute and a research assistant professor of sociology at the University of New Hampshire (beth.mattingly@unh.edu).

\section{A C K N O W L E D G M E N T S}

The authors thank the following individuals for their thoughtful comments and suggestions: Todd DeMitchell and Suzanne Graham in the Department of Education at the University of New Hampshire; Bruce Mallory, at the Carsey Institute and in the Department of Education at the University of New Hampshire; and Curt Grimm, Laurel Lloyd, and Amy Sterndale at the Carsey Institute.

\section{ANIVERSITY
of NEW HAMPSHIRE}

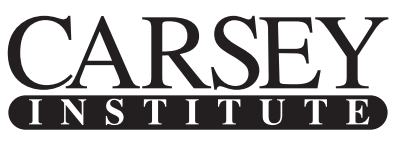

Building knowledge for families and communities

The Carsey Institute conducts policy research on vulnerable children, youth, and families and on sustainable community development. We give policy makers and practitioners timely, independent resources to effect change in their communities.

This work was supported by the Annie E. Casey Foundation, the W. K. Kellogg Foundation, and an anonymous donor.

Huddleston Hall

73 Main Street

Durham, NH 03824

(603) $862-2821$

www.carseyinstitute.unh.edu 